\title{
CHARACTERIZATION OF STAPHYLOCOCCUS EPIDERMIDIS ISOLATES CULTURED FROM PATIENTS WITH INFECTED HIP PROSTHESES
}

\section{CHARAKTERYSTYKA IZOLATÓW STAPHYLOCOCCUS EPIDERMIDIS WYHODOWANYCH OD PACJENTÓW Z ZAKAŻENIAMI ENDOPROTEZ STAWU BIODROWEGO}

\author{
Agnieszka Bogut $^{1(\mathrm{~A}, \mathrm{C}, \mathrm{D}, \mathrm{E}, \mathrm{F})}$, Justyna Niedźwiadek ${ }^{1(\mathrm{~A}, \mathrm{~F})}$, Dagmara Strzelec-Nowak ${ }^{1(\mathrm{~A}, \mathrm{D})}$, \\ Dorota Plewik $^{2(\mathrm{C}, \mathrm{D}, \mathrm{E})}$, Tomasz Mazurkiewicz ${ }^{1(\mathrm{~B})}$, Wojciech Marczyński ${ }^{3(\mathrm{~B})}$, Alina Olender ${ }^{1(\mathrm{~F})}$ \\ ${ }^{1}$ Medical University in Lublin, Poland \\ ${ }^{2}$ Research Centre for Innovation, Pope John Paul II State School of Higher Education in Biala Podlaska, Poland \\ ${ }^{3}$ Orthopaedics Ward of the Public Clinical Hospital of Prof. Adam Gruca in Otwock, Poland
}

Authors' contribution Wkład autorów:

A. Study design/planning zaplanowanie badań

B. Data collection/entry zebranie danych

C. Data analysis/statistics dane - analiza i statystyki D. Data interpretation interpretacja danych

E. Preparation of manuscript przygotowanie artykułu F. Literature analysis/search wyszukiwanie i analiza literatury G. Funds collection zebranie funduszy

\section{Summary}

Background. Coagulase negative staphylococci are at the forefront of etiologic agents of periprosthetic joint infections (PJIs). The purpose of the study was to characterise causative isolates $(\mathrm{n}=19)$ of Staphylococcus epidermidis (SE) - with emphasis on their phenotypic and genotypic heterogeneity. Material and methods. The isolates were cultured from multiple samples obtained perioperatively during revision surgery from 14 patients with clinically and/or microbiologically proven PJI. Phenotypic heterogeneity included variations of colony morphologies, drug resistance patterns and/or the capability of the biofilm formation and was verified by the DNA fingerprinting assay. Results. Phenotypic discrepancies were observed between isolates cultured from 5 patients (35.7\%). The genotyping assay identified 3 pairs of isolates as unrelated; single pairs were genetically related and indistinguishable. The biofilm production was detected in 17 isolates, among which $5(29.4 \%)$ were proficient biofilm formers harbouring the icaADBC genes. Additionally, one ica-positive isolate produced a moderate, protease-sensitive biofilm. The remaining isolates were moderate biofilm producers among which four developed protease-sensitive biofilms. Conclusions. The majority of PIIs are monoclonal; nevertheless, phenotypic diversity of SE is a frequent phenomenon which can complicate the diagnostic proceeding. Adherence ability is an important pathogenic trait of SE although the chemical composition of the resultant biofilm, its intensity and regulation of development can vary.

Keywords: prosthetic joint infection, Staphylococcus epidermidis, biofilm, heterogeneity

Streszczenie
Wprowadzenie. Gronkowce koagulazo-ujemne są wiodącymi czynnikami etiologicznymi
zakażeń okołoprotezowych. Celem pracy była charakterystyka izolatów (n=19)
Staphylococcus epidermidis (SE) ze szczególnym uwzględnieniem ich fenotypowej
i genotypowej heterogenności. Materiał i metody. Izolaty gronkowców zostały wyhodowane
z materiałów klinicznych pobranych śródoperacyjnie od 14 pacjentów, u których zakażenie
endoprotezy stawu biodrowego zostało potwierdzone klinicznie i/lub mikrobiologicznie.
Fenotypową heterogenność definiowano w oparciu o odmienne cechy morfologii kolonii
bakteryjnych, profile lekowrażliwości izolatów i/lub ich zdolność tworzenia biofilmu
w warunkach in vitro i weryfikowano ją na postawie genotypowania. Wyniki. Fenotypowe
rozbieżności zaobserwowano pomiędzy izolatami SE wyhodowanymiod 5 (35.7\%) pacjentów.
W oparciu o wyniki genotypowania za genetycznie niespokrewnione uznano 3 pary izolatów,
pojedyncze pary zaś za spokrewnione i nieodróżnialne/klonalne. Wytwarzanie biofilmu
zostało potwierdzone dla 17 badanych izolatów, wśród których 5 (29.4\%) wytwarzało
intensywny biofilm i posiadało geny icaADBC. Ponadto, jeden izolat SE ica+ wytwarzał
umiarkowany, wrażliwy na działanie proteazy biofilm. Pozostałe izolaty wytwarzały biofilm
umiarkowany. Cztery z nich charakteryzowały się tworzeniem biofilmu wrażliwego na
działanie proteazy. Wnioski. Większość PJIs ma charakter monoklonalny, niemniej jednak
zmienność fenotypowa SE pozostaje częstym zjawiskiem, co może utrudniać diagnostykę
zakażeń wywoływanych przez te drobnoustroje. Zdolność adherencji jest ważną cechą
warunkującą patogenność SE, aczkolwiek skład chemiczny powstającego w jej wyniku
biofilmu oraz jego intensywność i regulacja mechanizmów wpływąących na jego tworzenie
mogą różnić się pomiędzy izolatami.

Słowa kluczowe: zakażenie okołoprotezowe, Staphylococcus epidermidis, biofilm, heterogenność
Tables: 1

References: 21

Submitted: 2016 Nov 03

Accepted: 2017 Jan 30

Bogut A, Niedźwiadek J, Strzelec-Nowak D, Plewik D, Mazurkiewicz T, Marczyński W, et al. Characterization of Staphylococcus epidermidis isolates cultured from patients with infected hip prostheses. Health Prob Civil. 2018; 12(2): 132-138. https://doi.org/10.5114/hpc.2018.75491

Address for correspondence / Adres korespondencyjny: Agnieszka Bogut, Medical University in Lublin, Chodźki 1, 20-093 Lublin, Poland, e-mail: agnieszka. bogut@gmail.com, phone: +48 814486410

Copyright: (C Pope John Paul II State School of Higher Education in Biała Podlaska, Agnieszka Bogut, Justyna Niedźwiadek, Dagmara Strzelec-Nowak, Dorota Plewik, Tomasz Mazurkiewicz, Wojciech Marczyński, Alina Olender. This is an Open Access journal, all articles are distributed under the terms of the Creative Commons Attribution-NonCommercial-ShareAlike 4.0 International (CC BY-NC-SA 4.0) License (http://creativecommons.org/licenses/by-nc-sa/4.0/), allowing third parties to copy and redistribute the material in any medium or format and to remix, transform, and build upon the material, provided the original work is properly cited and states its license. 


\section{Introduction}

Prosthetic joint replacement surgery (arthroplasty) is considered one of the most successful orthopaedic procedures since each year it substantially improves the quality of life for thousands of patients. Nevertheless, infections of prosthetic joints, although rare, are among the most devastating complications of arthroplasty [13]. In the prior studies, we investigated various aspects of the pathogenesis and the diagnosis of prosthetic joint infections (PJIs). We reported the significance of the combination of sonication and conventional culture for the identification of microorganisms involved in the aetiology of these infections [4]. We investigated the spectrum of causative agents of PJIs and analysed their antibiotic resistance profiles [5]. We also studied an aspect of the pathogenesis of PJIs linked to naturally occurring microbial subpopulations called small-colony variants (SCVs) [6] which exhibit physiologic, biochemical, and colonial morphologies different from usual isolates [7].

In the present study, we focused on the characterisation of $S$. epidermidis isolates representing the normal phenotype with emphasis on their phenotypic and genotypic heterogeneity. S. epidermidis is a predominant species among coagulase-negative staphylococci (CNS) involved in the aetiology of PJIs [1, 8, 9]. Phenotypic heterogeneity of the investigated isolates was based on the observation of variations concerning colony morphologies, drug resistance patterns and/or the capability of the biofilm formation. The prevalence of the $i c a$ operon which encodes for the polysaccharide intercellular adhesion (PIA) - the most common molecule involved in intercellular adhesion during the biofilm formation by S. epidermidis [2] - was also examined. Phenotypically distinct isolates were characterised genetically to verify the nature of infection associated with the possibility of variation of the causative strain on the phenotypic level, genetic instability of a single infectious clone or a polyclonal mixture of strains.

\section{Material and methods}

To address the purpose of the study, we employed 19 isolates recovered from 14 patients with PJIs. The patients underwent their prosthetic hip joint revision procedures in the period between April 2010 and January 2012 at the Orthopaedics and Traumatology Ward of the Clinical Hospital in Lublin, Poland, and at the Public Clinical Hospital in Otwock, Poland. The clinical samples collected for microbiological studies included: synovial fluid (SVF), at least three intraoperative periprosthetic tissue samples (PTs) per patient and the sonicate fluid (SF). The SF was obtained after the sonication of explanted prostheses in order to disintegrate bacterial biofilm on the implants. The laboratory proceedings aimed at the cultivation of underlying pathogens were described in detail in our previous publications [4-5]. All staphylococcal isolates were considered clinically significant following the PJI definition by Parvizi et al. [10]. The isolates were identified to the species level using commercially available biochemical tests (API, BioMérieux, France); their antibiotic resistance profiles were determined according to the European Committee on Antimicrobial Susceptibility Testing (EUCAST) recommendations. The isolates used in this study are presented in Table 1.

\section{Repetitive sequence-based PCR (rep-PCR)}

Genetic relatedness between phenotypically divergent $S$. epidermidis isolates was verified by the Rep-PCR (Diversilab Staphylococcus DNA fingerprinting kit BioMérieux, France). The procedure of staphylococcal DNA isolation, its amplification conditions as well as the analysis of the rep-PCR products were described in our previous publication [6].

\section{Biofilm production}

The ability of cultured $S$. epidermidis isolates to produce biofilm was assessed by the PCR detection of the ica $A D B C$ genes and phenotypically - with the use of the quantitative microtiter plate assay (MPA). The procedure of bacterial DNA isolation and as well as the ica primer sequences and the amplification conditions are included in our previous publication [6]. The MPA was followed by the addition of trypsin in order to investigate proteinmediated mechanisms of the biofilm production [6]. For all methods, a reference strain of S. epidermidis ATCC 35984 was used as a positive control. 


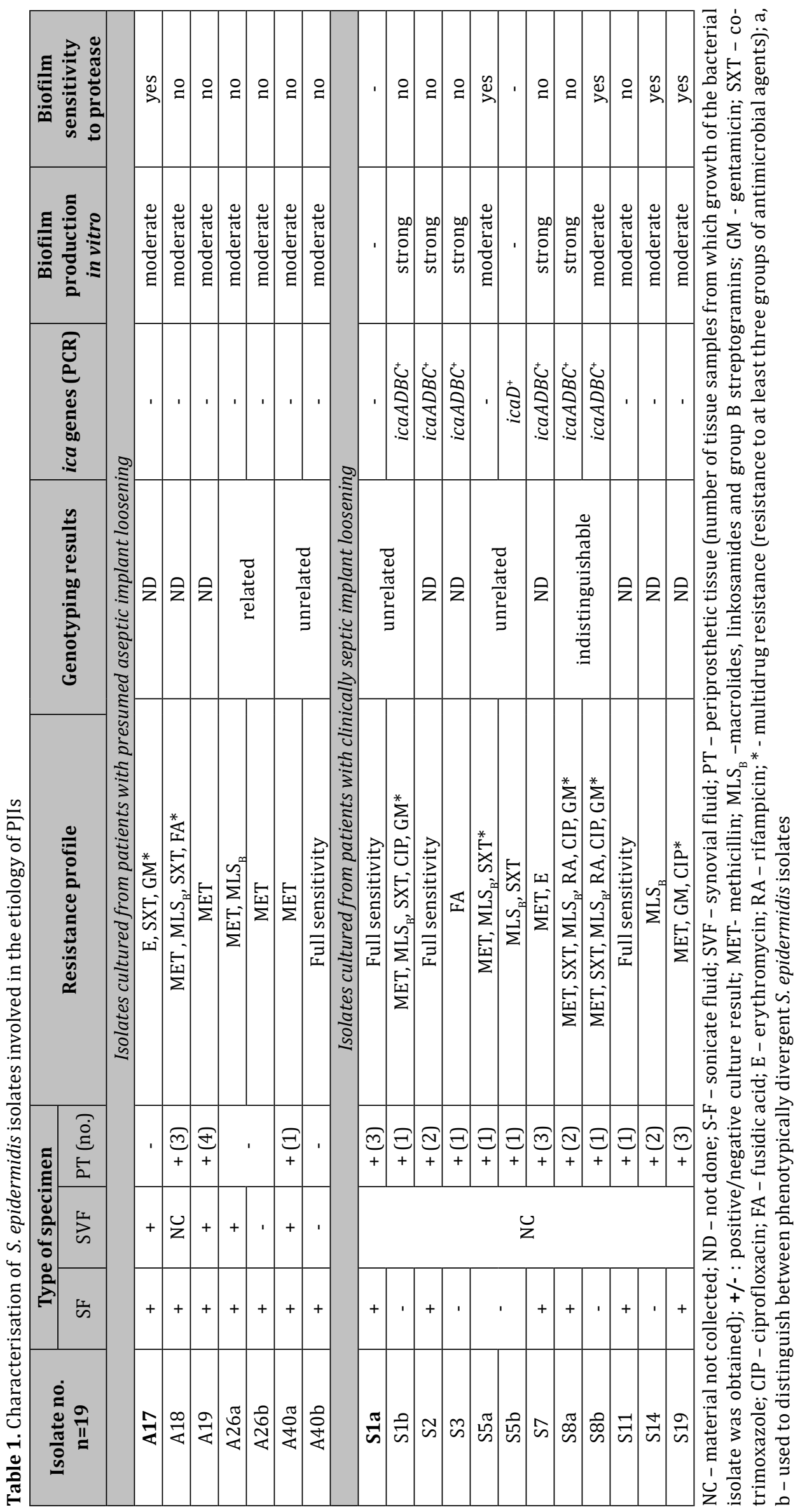




\section{Results and discussion}

Staphylococci are known for their pronounced phenotypic variability including a variety of properties such as colony morphology, growth rate, antibiotic susceptibility or the biofilm production [20]. This phenomenon is assumed to provide an evolutionary advantage which helps the bacteria to adapt to changing environmental conditions [21]. Our study revealed phenotypic discrepancies between S. epidermidis isolates cultured from 5 patients ( $35.7 \%$ ) (Table 1). These isolates were subsequently identified as unrelated (3 pairs), related (1 pair) or indistinguishable (1 pair) (Figure 1).

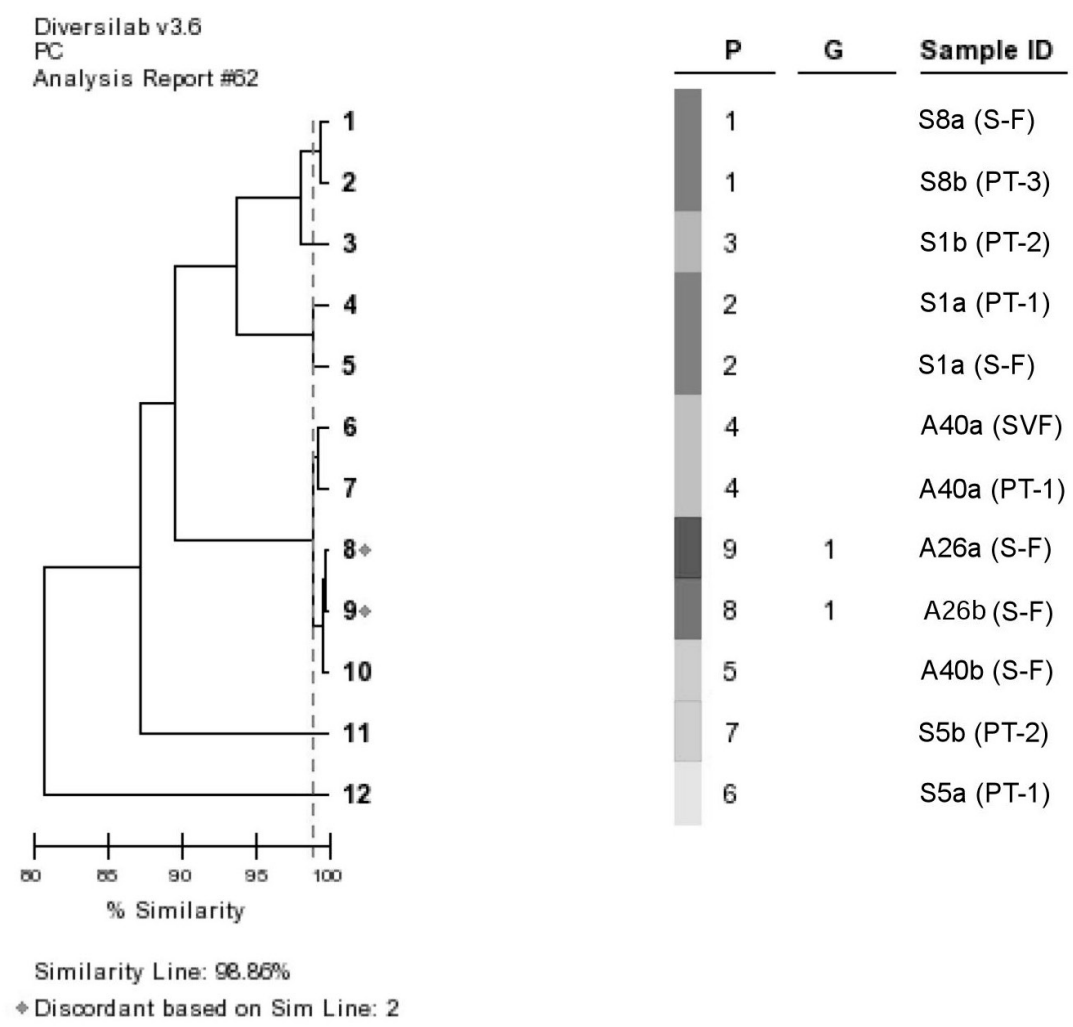

Figure 1. The rep-PCR fingerprinting results of phenotypically distinct $S$. epidermidis isolates

$\mathrm{P}$ - pattern; G - group;

S-F - sonicate-fluid

PT- periprosthetic tissue

SVF - synovial fluid

Designations of isolates and interpretation of the molecular fingerprinting assay:

Unrelated pairs:

S1a (S-F) and S1a (PT-1) -unrelated to S1b (PT-2)

$\mathrm{A} 40 \mathrm{a}$ (SVF) and A40 a (PT-1) - unrelated to A40b (S-F)

S5a (PT-1) and S5b (PT-2)

Related pairs:

A26a (S-F) and A26b (S-F)

Indistinguishable pairs:

S8a (S-F) and S8b (PT-3)

Hence, we conclude that most PJIs were in fact monoclonal; polyclonal infections were reported for the minority of the patients (21\%). Interestingly, this observation coincided with the rate (20\%) of polyclonal PJIs caused by S. epidermidis in the study of Nilsdotter-Augustinsson et al. [16]. Galdbart et al. [3], who compared the genomes of phenotypically divergent $S$. epidermidis strains detected in pus and infected tissue specimens from 14 patients with chronic PJIs, also noted that most patients were infected by a single S. epidermidis clone which subsequently underwent rearrangements that yielded derivatives with divergent phenotypes and, occasionally, divergent macrorestriction patterns.

S. epidermidis causes PJIs primarily through its ability to adhere to prosthetic materials with subsequent biofilm formation which is considered a critical step in the development and maintenance of these infections 
due to interference with the host immune system and antimicrobial agents. Many S. epidermidis strains produce a poly-N-acetylglucosamine (PNAG) homopolimer also named PIA that surrounds and connects staphylococcal cells in a biofilm. Its biosynthesis is accomplished by the gene products of the ica locus $[8,11,12]$. Although initial reports suggested the predominant role the ica gene cluster in the pathogenesis of device-related infections and proved its usefulness as a marker of the invasive capacity of S. epidermidis [13, 14] further studies have brought conflicting results. It has been recognized that the PIA is not essential for the biofilm formation in all S. epidermidis strains $[15,16]$ as in some strains the biofilm production can be mediated additionally or exclusively by specific surface proteins $([2,11,17,18]$. The results of our study have fit in the trend undermining the ubiquitous incidence and the key role of the ica operon as a marker of pathogenicity involved in the biofilm formation by clinical strains of $S$. epidermidis. We identified a complete set of the ica genes in staphylococcal isolates cultured from 5 patients (35.7\%) (Table 1); this observation is in line with data published by NilsdotterAugustinsson et al. [16] who identified the ica operon in S. epidermidis cultured from 5 out of 15 patients (33.3\%) with hip prosthesis infections. It should be noted that, in our study, the presence of the ica genes was detected only among isolates cultured from patients with a sinus tract accompanying the implant failure but not from those whose prosthesis loosening was presumed aseptic due to the lack of clinical manifestations of an ongoing PJI. Hence, it is conceivable that the ica-positive S. epidermidis can be responsible for more aggressive, clinically overt course of PJIs as they were the most profuse biofilm producers in the applied in vitro assay. Our results have also demonstrated that all four (icaA - icaD) ica genes are required for the synthesis of the functional PIA as one isolate which harboured the icaD gene only, was biofilm-negative. The icaADBC-negative $S$. epidermidis isolates $(\mathrm{n}=12)$, in turn, showed a moderate degree of the biofilm production in the in vitro assay with the exception of one isolate which did not demonstrate the biofilm formation capability, at least under applied in vitro conditions. The sensitivity of the biofilm to trypsin was observed for four ica-negative isolates (36.3\%) (Table 1). This observation was suggestive of the involvement of alternative, protein-mediated mechanisms of the biofilm formation. The finding of a moderate degree of adhesion was also consistent with observations made earlier by Rohde et al. [18] implying that the PIA-independent biofilms are weaker than those associated with the production of the polysaccharide adhesin. According to the authors, $27 \%$ of all biofilm-positive S. epidermidis strains identified in their study produced protease-sensitive biofilms indicating that protein factors can be sufficient for the biofilm formation in PJIs. On the other hand, our observation that seven ica-negative isolates sustained their moderate adherence ability after treatment with the proteolytic enzyme can be suggestive of the involvement of other factors like carbohydrates other than PIA, teichoic acids, or nonspecific physicochemical forces in the biofilm production [19].

Additionally, we identified one ica-positive isolate which most probably did not express the PIA. Its biofilm formation was presumably based on protein-mediated mechanisms since the adherence ability was lost after the application of the protease and the biofilm was not as robust as biofilms produced by other ica-positive isolates including its clonal counterpart (Table 1): This finding exemplifies variable biofilm production on the phenotypic level which can occur even within the same strain and is consistent with observations made previously [16, 19].

One case of the polyclonal infection detected in our study is also worth noting in more detail - one intrapatient strain cultured from the SF and three types of PTs was biofilm-negative and sensitive to all antimicrobials tested whereas another strain cultured from a single PT sample was not only multidrug-resistant but also ica- and biofilm-positive (Table 1). We assume of the clinical significance of both strains due to the number of clinical samples which yielded the growth of the former strain and the pathogenic potential (multidrug resistance, biofilm production) of the latter. Moreover, collection of the clinical samples and microbiological diagnostic proceedings were conducted under rigorously aseptic conditions. This finding clearly indicates the necessity of a thorough investigation of all colony morphologies due to the risk of infection with bacterial strains differing in their pathogenic potential including antibiotic resistance pattern.

\section{Conclusions}

The majority of PJIs are monoclonal, nevertheless, phenotypic diversity of SE is a frequent phenomenon which can complicate the diagnostic proceeding. The ability to produce biofilm appears to remain a key virulence trait of $S$. epidermidis involved in the pathogenesis of PJIs but, as it has been demonstrated, the regulation of its production, its intensity and chemical composition may be variable - even within the same strain. The knowledge on the possibility of infection caused by phenotypically and, occasionally, by genetically distinct isolates, should expand directions of the laboratory proceedings aimed at the isolation, characterisation and eradication of etiologic agents of PJIs. 


\section{Acknowledgements}

This study was approved by the local Ethical Review Board. All eligible patients agreed to take part in the study and gave written consent prior to study enrolment.

No external funding was received to conduct the study. There are no commercial relationships or potential conflicts of interest related to the submission.

\section{References:}

1. Al Mohajer M, Darouiche RO. The expanding horizon of prosthetic joint infections. J Appl Biomater Funct Mater. 2014; 12: 1-12. https://doi.org/10.5301/jabfm.5000202

2. Hellmark B, Söderquist B, Unemo M, Nilsdotter-Augustinsson Å. Comparison of Staphylococcus epidermidis isolated from prosthetic joint infections and commensal isolates in regard to antibiotic susceptibility, agr type, biofilm production, and epidemiology. Int J Med Microbiol 2013b; 303: 32-39.

https://doi.org/10.1016/j.ijmm.2012.11.001

3. Galdbart J-O, Morvan A, Desplaces N, El Solh N. Phenotypic and genomic variation among Staphylococcus epidermidis strains infecting joint prostheses. J Clin Microbiol 1999; 37: 1306-1312.

4. Bogut A, Niedźwiadek J, Kozioł-Montewka M, Strzelec-Nowak D, Blacha J, Mazurkiewicz T, et al. Sonication as a diagnostic approach used to investigate the infectious etiology of prosthetic hip joint loosening. Pol J Microbiol. 2014a; 63: 299-306.

5. BogutA, Niedźwiadek J, Strzelec-Nowak D, Blacha J, Mazurkiewicz T, Marczyński W, etal. Infectious prosthetic hip joint loosening: bacterial species involved in its aetiology and their antibiotic resistance profiles against antibiotics recommended for the therapy of implant-associated infections. New Microbiol. 2014c; 37: 209-18.

6. Bogut A, Niedźwiadek J, Kozioł-Montewka M, Strzelec-NowakD, Blacha J, Mazurkiewicz T, et al. Characterization of Staphylococcus epidermidis and Staphyloccocus warneri small-colony variants associated with prostheticjoint infections. J Med Microbiol. 2014b; 63: 176-85. https://doi.org/10.1099/jmm.0.066068-0

7. Maduka-Ezeh AN, Greenwood-Quaintance KE, Karau MJ, Berbari EF, Osmon DR, Hanssen AD, et al. Antimicrobial susceptibility and biofilm formation of Staphylococcus epidermidis small colony variants associated with prosthetic joint infection. Diagn Microbiol Infect Dis. 2012; 74: 224-9.

https://doi.org/10.1016/j.diagmicrobio.2012.06.029

8. Koskela A, Nilsdotter-Augustinsson A, Persson L, Söderquist B. Prevalence of the ica operon and insertion sequence IS256 among Staphylococcus epidermidis prosthetic joint isolates. Eur J Clin Microbiol Infect Dis 2009; 28: 655-660. https://doi.org/10.1007/s10096-008-0664-6

9. Lass R, Giurea A, Kubista B, Hirschl AM, Graninger W, Presterl E, et al. Bacterial adherence to different components of total hip prosthesis in patients with prosthetic joint infection. Int Orthop 2014; 38: 15971602. https://doi.org/10.1007/s00264-014-2358-2

10. Parvizi J,Zmistowski B, Berbari EF, BauerTW,Springer BD, Della Valle CJ, etal. New definitionfor periprosthetic joint infection. J Arthroplasty 2011; 26(8): 1136-1138. https://doi.org/10.1016/j.arth.2011.09.026

11. Otto M. Staphylococcus epidermidis - the "accidental” pathogen. Nat Rev Microbiol 2009; 7: 555-567. https://doi.org/10.1038/nrmicro2182

12. Hellmark B, Berglund C, Nilsdotter-Augustinsson Å, Unemo M, Söderquist B. Staphylococcal cassette chromosome mec (SCCmec) and arginine catabolic mobile element (ACME) in Staphylococcus epidermidis isolated from prosthetic joint infections. Eur J Clin Microbiol Infect Dis 2013a; 32: 691-697. https://doi.org/10.1007/s10096-012-1796-2

13. Ziebuhr W, Krimmer V, Rachid S, Lössner I, Götz F, Hacker J. A novel mechanism of phase variation of virulence in Staphylococcus epidermidis: evidence for control of the polysaccharide interellular adhesin synthesis by alternating insertion and excision of the insertion sequence element IS256. Mol Microbiol 1999; 32: 345-356. https://doi.org/10.1046/j.1365-2958.1999.01353.x

14. Galdbart J-O, Allignet J, Tung H-S, Rydèn C, El Solh N. Screening for Staphylococcus epidermidis markers discriminating between skin-flora strains and those responsible for infections of joint prostheses. J Infect Dis 2000; 182: 351-355. https://doi.org/10.1086/315660

15. Frank KL, Hanssen AD, Patel R. icaA is not a useful marker for prosthetic joint infection. J Clin Microbiol 2004; 42: 4846-4849. https://doi.org/10.1128/jcm.42.10.4846-4849.2004

16. Nilsdotter-Augustinsson $\AA$, Koskela A, Öhman L, Söderquist B. Characterization of coagulase-negative staphylococci isolated from patients with infected hip prostheses: use of phenotypic and genotypic analyses, including tests for the presence of the ica operon. Eur J Clin Microbiol Infect Dis 2007; 26: 255-265. https://doi.org/10.1007/s10096-007-0281-9 
17. Rohde H, Knobloch JKM, Horstkotte MA, Mack D. Correlation of biofilm expression types of Staphylococcus epidermidis with polysaccharide intercellular adhesin synthesis: evidence for involvement of icaADBC genotype-independent factors. Med Microbiol Immunol 2001; 190: 105-12.

18. Rohde H, Burandt EC, Siemssen N, Frommelt L, Burdelski C, Wurster S, et al. Polysaccharide intercellular adhesin or protein factors in biofilm accumulation of Staphylococcus epidermidis and Staphylococcus aureus isolated from prosthetic hip and knee joint infections. Biomaterials 2007; 28: 1711-1720. https://doi.org/10.1016/j.biomaterials.2006.11.046

19. Chokr A, Watier D, Eleaume H, Pangon B, Ghnassia J-C, Mack D, et al. Correlation between biofilm formation and production of polysaccharide intercellular adhesion in clinical isolates of coagulase-negative staphylococci. Int J Med Microbiol 2006; 296: 381-388. https://doi.org/10.1016/j.ijmm.2006.02.018

20. Becker K, Bierbaum G, von Eiff Ch, Engleman S, Götz F, Hacker M, et al. Understanding the physiology and adaptation of staphylococci: a post-genomic approach. Int J Med Microbiol 2007; 297: 483-50. https://doi.org/10.1016/j.ijmm.2007.04.004

21. Kozitskaya S, Cho S-H, Dietrich K, Marre R, Naber K, Ziebuhr W. The bacterial insertion sequence element IS256 occurs preferentially in nosocomial Staphylococcus epidermidis isolates: association with biofilm formation and resistance to aminoglycosides. Infect Immun 2004; 72: 1210-1215. 